\title{
SISTEM INFORMASI MANAJEMEN PENGGAJIAN DAN PENILAIAN KINERJA PEGAWAI PADA SMK TAMAN SISWA LAMPUNG
}

\author{
Damayanti $^{1}$, Nina Nirmalasari ${ }^{2}$ \\ ${ }^{1,2}$ Fakultas Teknik dan Ilmu Komputer, Universitas Teknokrat Indonesia \\ Email: 1damayanti@teknokrat.ac.id, ${ }^{2}$ ninanirmalasaritgs@gmail.com
}

(Naskah masuk: 19 Agustus 2018, diterima untuk diterbitkan: 02 Juli 2019)

\begin{abstract}
Abstrak
Sekolah Menengah Kejuruan Taman Siswa Teluk Betung merupakan salah satu sekolah swasta yang ada di Lampung yang memiliki 3 jurusan yaitu akuntansi, perkantoran, dan teknik komputer jaringan. Permasalahan dalam pengelolaan data penggajian dan penilaian kinerja guru/pegawai pada SMK Taman Siswa Teluk Betung masih dilakukan secara manual. Perhitungan gaji pegawai masih menggunakan kalkulator sehingga pengelolaan penggajian belum efektif dan efisien karena pengelolaan gaji tersebut rentan terjadi kesalahan perhitungan dan lambatnya dalam pembuatan laporan penggajian. Penilian kinerja guru/pegawai pada SMK Taman Siswa Teluk Betung belum baik karena hanya dilihat dari jumlah tingkat kehadiran dalam proses pembelajaran saja. Tujuan penelitian ini adalah membangun sistem informasi penggajian dan penilaian kinerja guru/pegawai. Metode yang digunakan dalam pengembangan sistem yaitu dengan model waterfall, dengan alat dan bahan pengembangannya memakai usecase, activity diagram, bahasa pemrograman $P H P$, dreamweaver, dan $M y S Q L$ sebagai basisdata. Teknik pengumpulan data yang digunakan adalah wawancara, observasi, studi pustaka, dan dokumentasi. Penelitian ini menghasilkan sistem informasi manajemen penggajian dan penilaian kinerja pegawai SMK Taman Siswa Teluk Betung yang dapat memberikan kemudahan dalam kegiatan manajemen penggajian dan penilaian kinerja pegawai. Penyampaian laporan penggajian dan hasil penilaian kinerja pegawai kepada pimpinan menjadi lebih cepat karena pimpinan dapat mengakses laporan melalui website. Temuan lain pada penelitian ini bahwa penilaian kinerja guru/pegawai dapat dilakukan secara langsung pada aplikasi melalui website sehingga penililaian kinerja guru/pegawai menjadi lebih efektif dan lebih efisien.
\end{abstract}

Kata kunci: Sistem informasi manajemen, penggajian, kinerja pegawai, aplikasi, waterfall

\section{PAYROLL MANAGEMENT INFORMATION SYSTEM AND PERFORMANCE ASSESSMENT OF EMPLOYEES AT SMK TAMAN SISWA LAMPUNG}

\begin{abstract}
Teluk Betung Vocational High School Taman Siswa is one of the private schools in Lampung which has 3 departments, namely accounting, office, and network computer engineering. Problems in managing payroll data and evaluating employee performance at Teluk Betung SMK Taman Siswa are still done manually. Employee salary calculations still use a calculator so that payroll management has not been effective and efficient because the salary management is prone to calculation errors and the slow creation of payroll reports. The assessment of teacher / employee performance at the Teluk Betung Vocational School is not good because it is only seen from the number of attendance levels in the learning process. The purpose of this study is to build a payroll information system and employee performance appraisal. The method used in the development of the system is the waterfall model, with its development tools and materials using usecase, activity diagrams, PHP, Dreamweaver, and MySQL as database. Data collection techniques used are interviews, observation, literature study, and documentation. This study produced a payroll management information system and employee performance appraisal at Teluk Betung Vocational School employees who can provide convenience in payroll management activities and employee performance appraisals. Submission of payroll reports and results of performance appraisals to leaders are faster because leaders can access reports through the website. The findings in this study that the assessment of teacher / employee performance can be done directly on the application through the website so that the assessment of teacher / employee performance becomes more effective and more efficient.
\end{abstract}

Keywords: Management information system, payroll, employee performance, waterfall 


\section{PENDAHULUAN}

Pemanfaatan teknologi informasi pada setiap kegiatan penyelenggaraan pemerintahan dilakasanakan untuk menuju good governance. Konsep good governance ini memerlukan sistem yang mampu memenuhi kebutuhan pelayanan yang cepat, tepat dan tidak berbelit - belit. Dengan penggunaan sistem informasi dimungkinkan adanya otomatisasi pekerjaan dan fungsi pelayanan untuk mewujudkan pelayanan yang baik termasuk otomatisasi dalam penanganan sistem kepegawaian seperti penggajian dan penilaian kinerja. Penggunaan komputer didalam sistem informasi manajemen sangat banyak membantu para manajer dalam proses pengambilan keputusan. Komputer dalam sistem informasi manajemen dirumuskan sebagai suatu perlengkapan elektronik yang mengolah data, mampu menerima masukan dan keluaran, memiliki kecepatan yang tinggi, ketelitian yang tinggi, dan mampu menyimpan insktruksi - instruksi untuk memecahkan masalah.

Sekolah Menengah Kejuruan Taman Siswa

Teluk Betung merupakan salah satu sekolah swasta yang ada di Lampung yang memiliki 3 jurusan yaitu akuntansi, perkantoran, dan teknik komputer jaringan. Sekolah menengah kejuruan Teluk Betung terdapat 30 pegawai atau guru yang memiliki tugasnya masing-masing antara lain kepala sekolah, tenaga administrasi sekolah, guru mata pelajaran dan guru bimbingan konseling dan ada beberapa guru yang memiliki tugas tambahan seperti wakil kepala sekolah, dan kepala perpustakaan. Permasalahan dalam pengelolaan data penggajian dan penilaian kinerja pegawai pada SMK Taman Siswa Teluk Betung masih dilakukan secara manual (Koes \& Rahajeng 2014), (Setiawan \& Yasdomi, 2016). Perhitungan gaji pegawai masih menggunakan kalkulator sehingga pengelolaan penggajian belum efektif dan efisien karena pengelolaan gaji tersebut rentan terjadi kesalahan perhitungan serta lambatnya dalam pembuatan laporan penggajian. Penilian kinerja guru/pegawai pada SMK Taman Siswa Teluk Betung belum baik karena masih dikelola secara manual (Agustina dkk. 2013), (Hutabarat, dkk, 2018), hanya dilihat dari jumlah tingkat kehadiran dalam proses pembelajaran saja.

Berdasarkan pada penelitian terdahulu cederung hanya membahas sistem informasi penggajian saja dan sistem informasi kinerja pegawai saja serta masih berbasis dekstop. Berdasarkan studi literatur yang penulis lakukan belum ada yang membahas penggabungan sistem informasi penggajian dan penilaian kinerja pegawai. Selain itu perbedaan penelitian ini dengan penelitian terdahulu yaitu menghasilkan sebuah aplikasi yang dapat mengelola penilaian kinerja pegawai dengan mengisi angket/vooting yang telah tersedia pada aplikasi berbasis website. Pada penelitian terdahulu cenderung masih berbasis dekstop (Agustina, dkk. 2013), (Natanael\& Mulyono, 2017). Pada penelitian terdahulu penilaian kinerja pun cenderung masih dengan cara menyebarkan angket secara manual. Penelitian ini membangun sistem informasi pengajian dan penilaian kinerja pegwai pada SMK Taman Siswa Teluk Betung. Sistem informasi penggajian dan penilaian kinerja pada SMK Taman Siswa sangat penting untuk dikembangkan untuk memperbaiki sistem yang ada, dengan dibangunnya sistem informasi penggajian dan penilaian kinerja guru/pegawai berbasis website ini diharapkan dapat memberikan kemudahan dalam kegiatan pengelolaan penggajian dan penilaian kinerja guru/pegawai pada SMK Taman Siswa Teluk Betung. Sistem informasi ini juga dapat mempercepat dalam pembuatan laporan gaji pegawai. Penyampaian informasi tentang gaji dan hasil penilaian kinerja kepada pimpinan/kepala sekola maupun kepada pegawai dapat menjadi lebih cepat. Penilaian kinerja guru/pegawai dapat dilakukan secara langsung pada aplikasi melalui website sehingga penilaian kinerja guru/pegawai menjadi lebih efektif dan lebih efisien (Natanael \& Mulyono, 2017). Kinerja karyawan harus selalu di optimalkan agar dapat memberikan kualitas pelayanan yang baik dan kepuasan kerja (Molly, dkk, 2017). Pada penelitan Yudihartanti, Y., Syahib Natarsyah, S., \& Arnie, R. (2017) menyatakan bahwa penerapan teknologi informasi diharapkan akan memudahkan untuk membuat programprogram pembinaan kedepan terhadap informasi yang diketahui dari hasil penilaian kinerja. Aplikasi yang dibuat dapat membantu pejabat penilai dalam menilai pegawainya. Sehingga dapat menghasilkan informasi untuk proses pembinaan pegawai (Agustina, dkk., 2013)

\section{METODOLOGI}

\subsection{Objek dan Lokasi Penelitian}

Penelitian ini membangun sistem informasi manajemen penggajian dan penilaian pegawai. Penelitian di dilaksanakan pada SMK Taman Siswa Teluk Betung. SMK Taman Siswa Teluk Betung merupakan salah satu sekolah swasta yang ada di Lampung yang memiliki 3 jurusan yaitu akuntansi, perkantoran, dan teknik komputer jaringan. SMK Taman Siswa Teluk Betung terdapat 30 pegawai atau guru yang memiliki tugasnya masing-masing antara lain kepala sekolah, tenaga administrasi sekolah, guru mata pelajaran dan guru bimbingan konseling dan ada beberapa guru yang memiliki tugas tambahan seperti wakil kepala sekolah, dan kepala perpustakaan.

\subsection{Tahapan Penelitian}

Tahapan pada penelitian ini dimulai dari tahap identifikasi masalah, mengembangkan sistem 
berbasis web, perancangan, implementasi, pengujian, hasil dan kesimpulan.

\subsection{Teknik Pengumpulan Data}

Teknik pengumpulan data pada penelitian ini adalah sebagai berikut:

a. Wawancara (Interview)

Teknik wawancara adalah teknik pengumpulan data atau informasi dilakukan dengan cara bertanya langsung kepada admin Sekolah Menengah Kejuruan Taman Siswa Teluk Betung. Metode wawancara semi structured kepada pihak SMK Taman Siswa yang berkaitan dengan pengelolaan gaji guru/pegawai dan prosedur penilian kinerja guru/pegawai.

Berikut list pertanyaan dalam wawancara:

1) Bagaimana pengelolaan gaji pada SMK Taman Siswa?

2) Apakah terdapat kendala dalam perhitungan gaji/pegawai?

3) Bagaimana perhitungan gaji guru/pegawai?

4) Apakah dalam pengelolaan gaji pegawai sudah menggunakan aplikasi khusus?

5) Bagaimana prosedur penilaian kinerja guru/pegawai selama ini?

6) Bagaimana teknik penilaian kinerja guru/pegawai yang digunakan?

7) Apakah sudah ada kreteria penilaian kinerja guru/pengawai yang digunakan?

8) Apa kendala dalam menentukan penilaian kinerja guru/pegawai?

9) Bagaimana pembuatan laporan penggajian dan laporan penilaian kinerja guru/pegawai?

10)Bagaimana penyajian laporan kepada pimpinan/kepala sekolah ?

\section{b. Observasi (Observation)}

Teknik observasi adalah teknik pengumpulan data dilakukan dengan cara pengamatan secara langsung pada data pegawai, proses penggajian dan kinerja pegawai.

c. Tinjauan Pustaka (Literature Review)

Teknik tinjauan pustaka adalah teknik pengumpulan data dilakukan dengan cara mempelajari berbagai artiket ilmiah, laporan laporan ilmiah, dan sumber bacaan serta buku buku yang berkaitan dengan topik penelitian.

d. Dokumentasi (Documentation)

Teknik dokumentasi adalah teknik pengumpulan data dilakukan dengan cara mengumpulkan beberapa dokumen yang diperlukan dalam penelitian.

\subsection{Analisis Kebutuhan Sistem}

Pembuatan sistem yang memerlukan beberapa kebutuhan yang nantinya akan dimanfaatkan dalam proses berjalannya sistem. Kebutuhan-kebutuhan yang sesuai dengan sistem yang diinginkan. Analisis kebutuhan menggunakan metode wawancara langsung kepada pimpinan/kepala sekolah dan guru/pegawai. Analisis yang dibutuhkan adalah sebagai berikut:

a. Kebutuhan Fungsional

Aplikasi yang dirancang sesuai dengan kebutuhan yang diharapkan dapat berjalan pada

SMK Taman Siswa Teluk Betung di Lampung.

Berikut merupakan kebutuhan fungsional:

1) Sistem dapat melakukan pengolahan data pegawai

2) Sistem dapat mengolah data jabatan pegawai

3) Sistem dapat mengolah data kelas

4) Sistem dapat mengolah rekap mengajar guru

5) Sistem dapat mengolah gaji pegawai

6) Sistem dapat mengolah data penilaian guru/pegawai

7) Sistem dapat mengolah laporan

b. Kebutuhan Non Funsional

Apapun kebutuhan nonfungsional terdiri dari perangkat hardware dan software yang digunakan dalam pembuatan sistem informasi manajemen penggajian dan penilaian kinerja guru/pegawai. Berikut kebutuhan non fungsional:

1) Perangkat hardware terdiri dari: prosesor i3, memory (RAM) 2 GB, hardisk 500GB, monitor, modem, keyboard, mouse, dan printer.

2) Perangkat software terdiri dari: windows7, excamp (Apache), PHP, Dreamwever, MySQL, browser chrome versi 5.0

\subsection{Perancangan Sistem}

Perancangan menggunakan usecase diagram. Usecase diagram merupakan pemodelan untuk penggambaran (kelakuan) sistem informasi yang akan dibuat. Perancangan usecase diagram sistem informasi manajemena penggajian dan penilaian kinerja pegawai pada SMK Taman Siswa Teluk Betung dapat dilihat pada gambar 1.

Pada diagram diatas terdiri dari 4 aktor yaitu admin, pegawai, siswa dan kepala sekolah/pimpinan. Usecase tersebut mendeskripsikan admin sebagai bagian yang menjalankan sistem. Admin melakukan login terlebih dahulu. Selanjutnya admin dapat mengolah data seperti: data guru/pegawai, jabatan, kelas, data rekap mengajar, mengelola penggajian 
dan penilaian guru/pegawai, serta mengelola laporan.

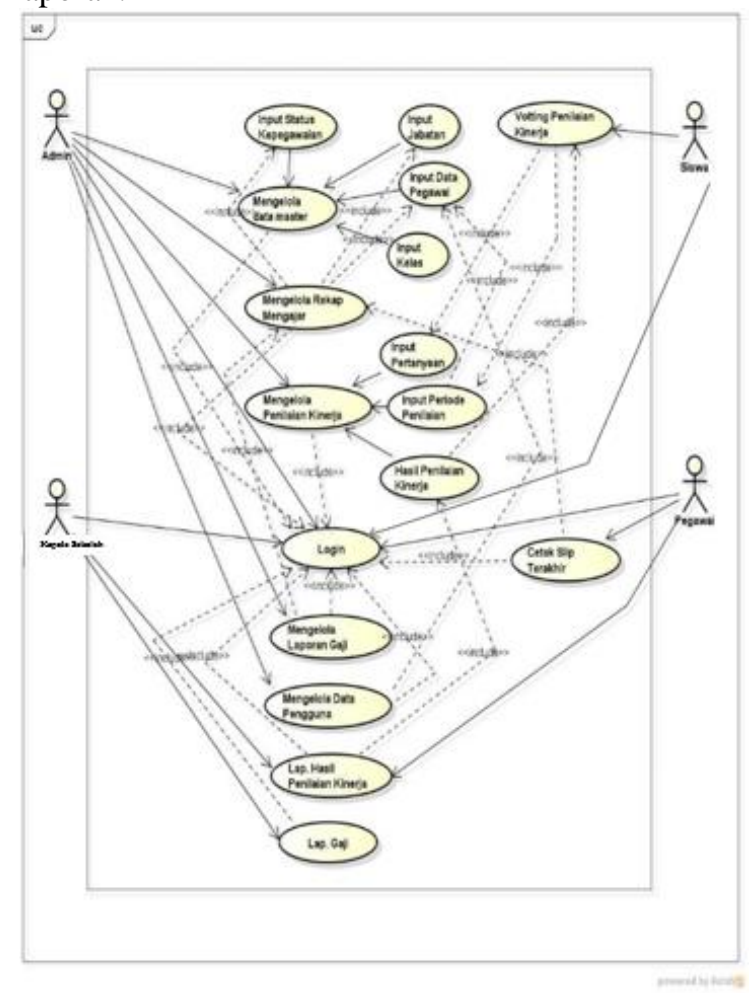

Gambar 1. Usecase Diagram

Pegawai dapat melihat slip gaji dan melihat hasil penilaian kinerja. Siswa melakukan login dan selanjutnya siswa dapat melakukan penilaian kinerja guru/pegawai dengan cara melakukan mengisi angket/votting secara online melalui website. Siswa merupakan user yang memberikan penilaian terhadap kinerja guru/pegawai selama proses pembelajaran yang telah dilakukan. Selanjutnya Pimpinanan/kepala sekolah dapat melihat laporan penggajian dan hasil penilaian kinerja pegawai secara online melalui website.

Activity Diagram memperlihatkan aliran dari suatu akvitas ke aktivitas lainnya dalam suatu sistem. Berikut merupakan activity diagram sistem informasi manajeman penggajian dan penilaian kinerja pegawai pada SMK Taman Siswa Teluk Betung.

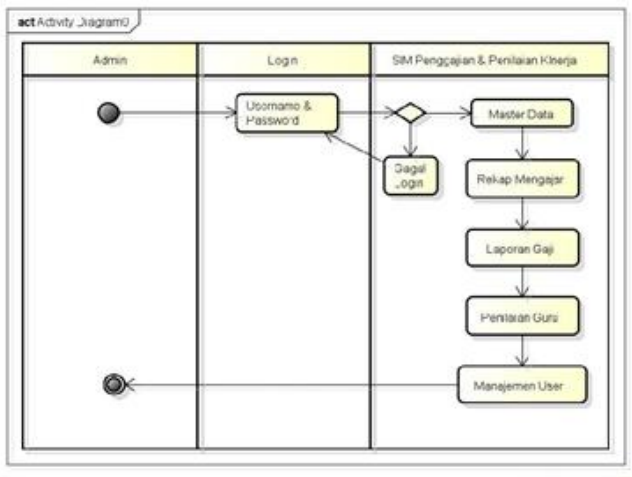

Gambar 2. Activity Diagram Admin

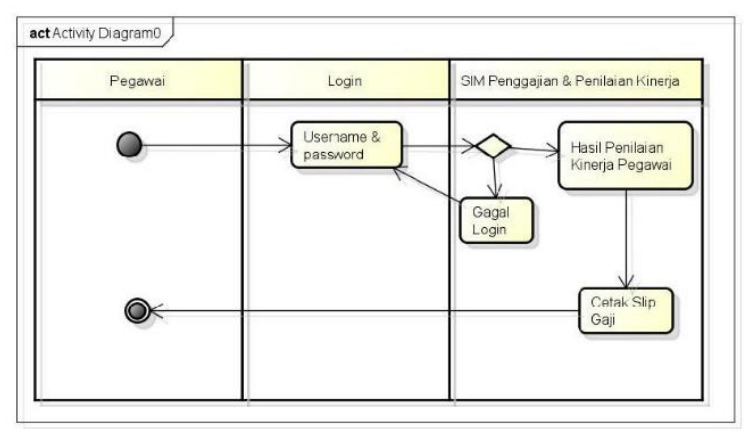

Gambar 3. Activity Diagram Pegawai

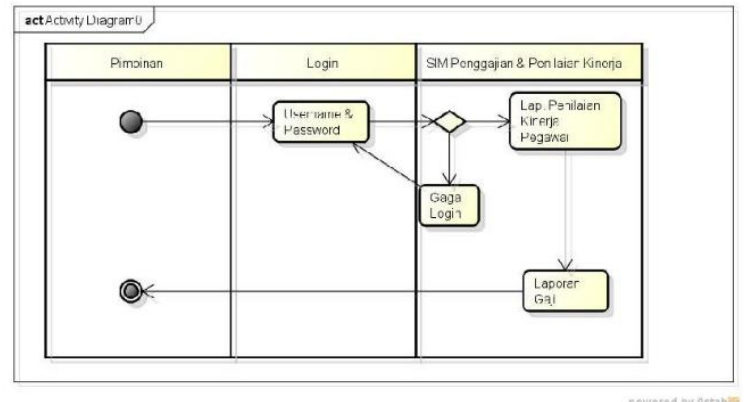

Gambar 4. Activity Diagram Pimpinan

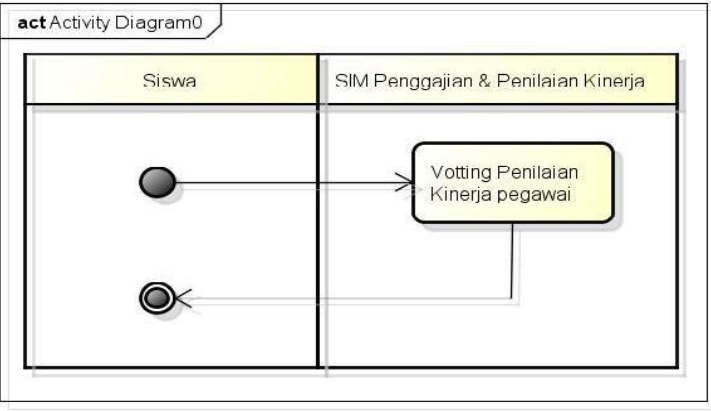

Gambar 5. Activity Diagram Siswa

\section{HASIL DAN PEMBAHASAN}

\subsection{Implemantasi Sistem}

Berdasarkan penelitian yang dilakaukan maka dapat disimpulkan penelitian ini menghasilkan sistem informasi manajemen penggajian dan penilaian kinerja pegawai. Sistem ini memberi kemudahan dalam manajemen atau pengelolaan penggajian dan penilaian kinerja pegawai. Sistem ini juga akan memberi kemudahan dalam penyampaian laporan kepada pimpinan. Pimpinan dapat langsung melihat laporan gaji perbulan maupun pertahun. Selanjutnya pimpinan juga dapat melihat laporan hasil penilaian kinerja pegawai/guru melalui website. Berikut merupakan implementasi program sistem informasi manajemen penggajian dan penilaian kinerja pegawai pada SMK Taman Siswa Teluk Betung. 
a. Menu Utama

Halaman utama merupakan tampilan depan sistem sebelum melakukan login. Menu utama dapat dilihat pada gambar 6 .

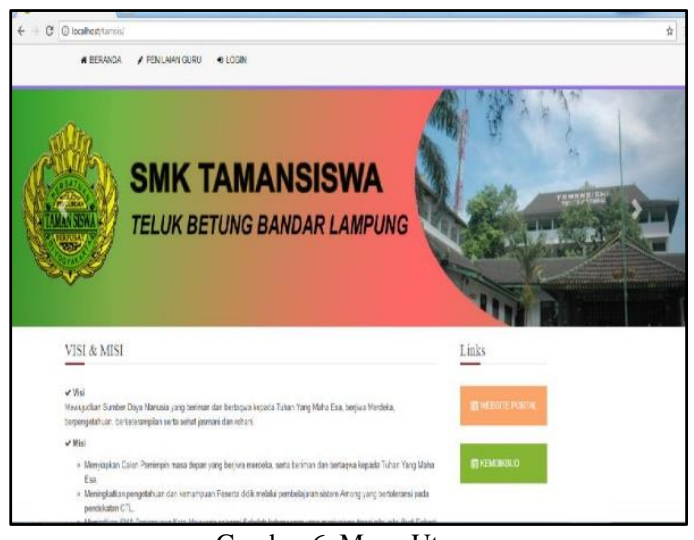

Gambar 6. Menu Utama

b. Menu Login

Menu login merupakan tampilan login yang digunakan untuk memasukkan username dan password yang telah ditentukan. Menu login dapat dilihat pada gambar 7 .

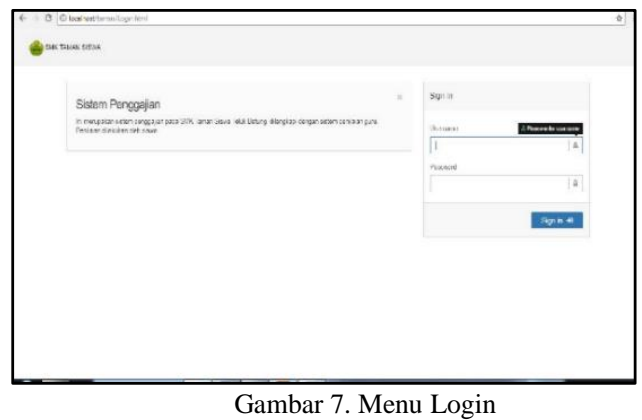

c. Menu Input Data Pegawai

Menu input data pegawai untuk meng-input-kan data pegawai yang menampilkan tentang biodata singkat pegawai seperti: NUPTK, nama, tanggal lahir, jenjang pendidikan, gelar, status jabatan, Menu input data pegawai dapat dilihat pada gambar 8 .

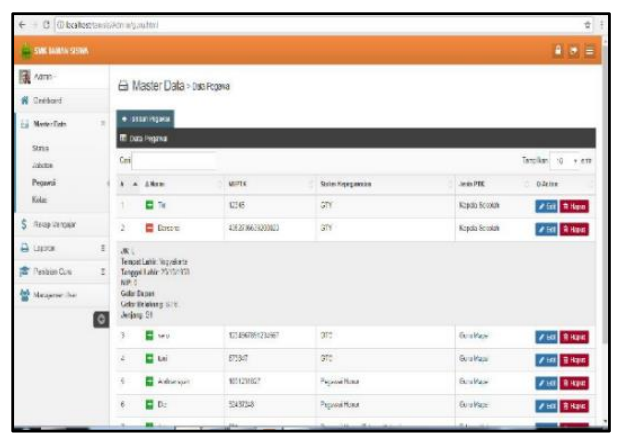

Gambar 8. Menu Input Data Pegawai d. Menu Input Data Jabatan

Menu data jabatan untuk menampilan tunjangan yang didapat oleh setiap pegawai/guru berdasarkan jabatan yang dimiliki. Menu jabatab dapat dilihat pada gambar 9 .

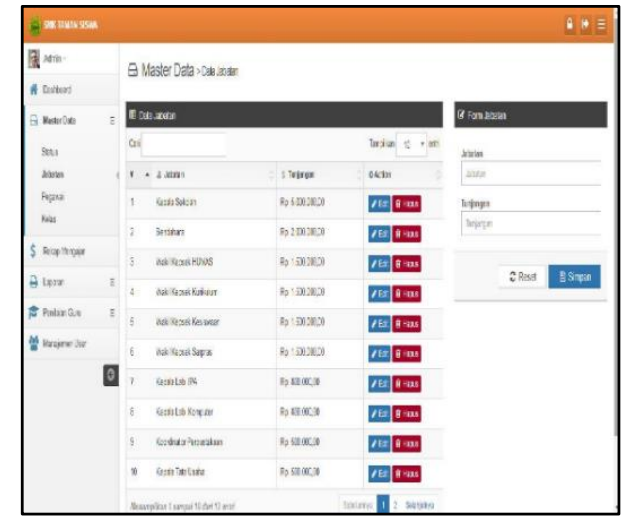

Gambar 9. Menu Data Jabatan

e. Data Kelas

Menu data kelas berfungsi untuk menginputkan data kelas yang akan dihubungkan dengan penilain kinerja pegawai/guru.

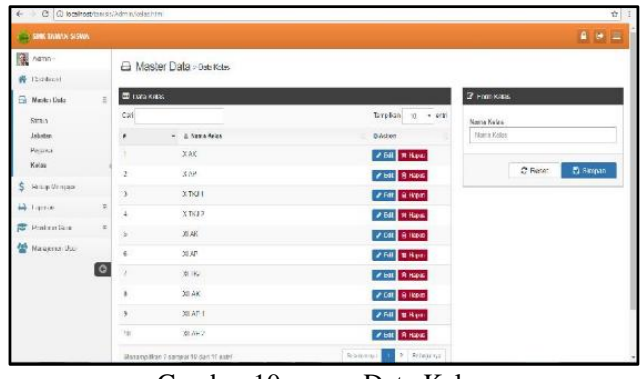

Gambar 10. menu Data Kelas

\section{f. Menu Data Rekap Mengajar}

Menu data rekap mengajar berfungsi untuk meng-input-kan data rekap mengajar yang digunakan untuk menghitung gaji pegawai setiap bulannya. Admin akan menginputkan jumlah jam mengajar guru dan kemudian akan diketahui jumlah gaji guru/pegawai perbulan.

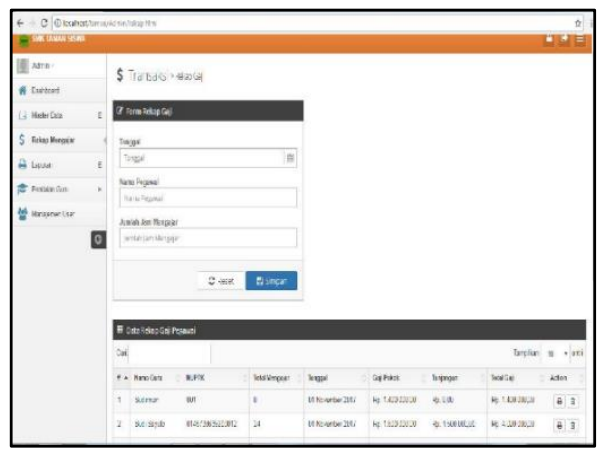

Gambar 11. Menu Data Rekap Mengajar 


\section{g. Menu Penggajian}

Menu penggajian berfungsi untuk melihat gaji pegawai.

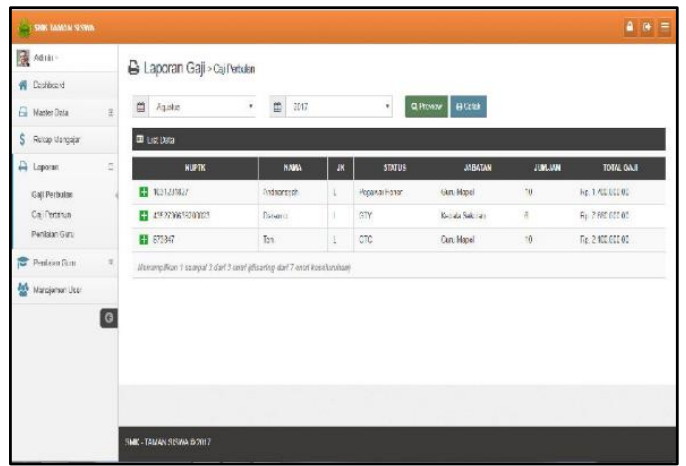

Gambar 12. Menu Penggajian

h. Menu Atur Pertanyaan

Menu atur pertanyaan berfungai untuk menginput-kan pertanyaan, dan nilai untuk setiap pertanyaan yang nantinya akan dilakukan votting oleh siswa.

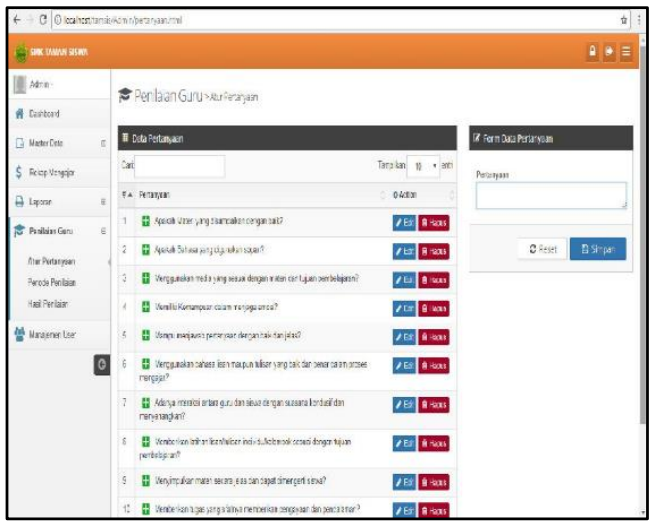

Gambar 13. Menu Atur Pertanyaan

i. Menu Penilaian Kinerja Guru

Menu penilaian kinerja guru berfungsi untuk mengetahui hasil penilaian kinerja guru. Penilaian kinerja guru dilakukan oleh siswa melalui website.

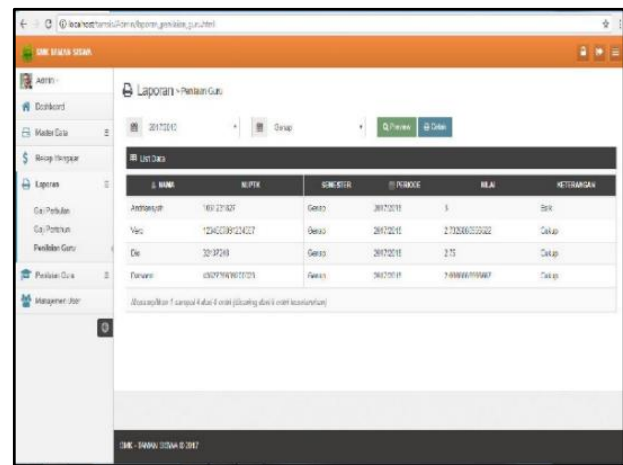

Gambar 14. Menu Penilaian Kinerja Guru/Pegawai j. Laporan Gaji Pegawai

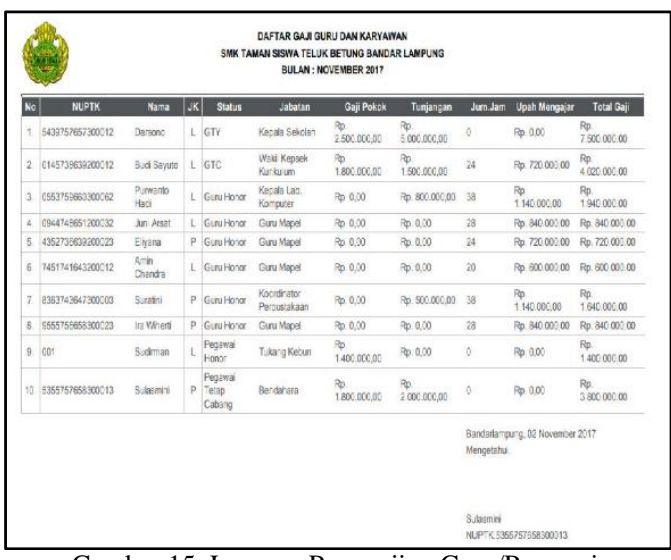

Gambar 15. Laporan Penggajian Guru/Pegawai

k. Laporan Penilaian Kinerja Guru/Pegawai

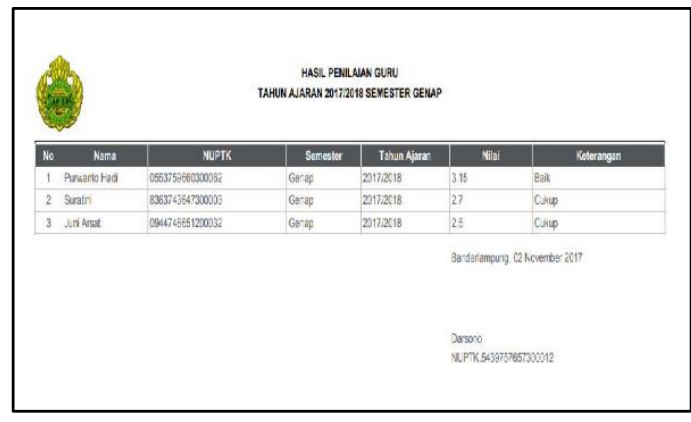

Gambar 16. Laporan Hasil Penilaian Kinerja Guru/Pegawai

\subsection{Pengujian Sistem}

Penggunjian sistem menggunakan pengujian blackbox. Pengujian kotak hitam (blackbox testing) merupakan salah satu metode pengujian perangkat lunak yang berfokus pada persyaratan fungsional perangkat lunak. Artinya, teknik pengujian kotak hitam memungkinkan untuk membuat beberapa kumpulan kondisi masukan yang sepenuhnya akan melakukan semua kebutuhan fungsional untuk program. Blackbox (blackbox testing) adalah salah satu metode pengujian perangkat lunak yang berfokus pada sisi fungsionalitas, khususnya pada input dan output aplikasi (apakah sudah sesuai dengan apa yang diharapkan atau belum). Hasil pengujian sistem ini menunjukkan bahwa aplikasi sudah sesuai dengan apa yang diharapkan oleh SMK Taman Siswa.

\section{KESIMPULAN}

Penelitian ini telah menghasilkan Sistem informasi manajemen penggajian dan penilaian kinerja pegawai berbasis website sehingga dapat mempermudah dalam pengelolaan penggajian dan penilaian kinerja guru/pegawai, sistem dapat menghitung jumlah gaji secara otomatis sehingga menjadi lebih efektif dan efisien. Sistem ini juga dapat mempermudah dalam pengelolaan laporan penggajian dan laporan penilaian kinerja guru/pegawai karena pimpinan dapat secara 
langsung mengakses laporan melalui website. Saran untuk penelitian selanjutnya hendaknya penelitian kedepan dapat dikembangakan sistem informasi penggajian dan penilaian kinerja berbasis mobile

\section{DAFTAR PUSTAKA}

AGUSTINA, D. M., \& DKK. 2013.Sistem Informasi Penilaian Kinerja Pegawai pada Badan Kepegawaian dan Diklat Surabaya, Jurnal Sistem Informasi, JSIKA. 2(2). 3642.

HUTABARAT, A., S. \& DKK, 2018. Analisis dan Perancangan Sistem informasi Penilaian Prestasi Kerja Pegawai pada Universitas Jambi. Jurnal Sains dan Sistem Informasi. 1(1). 30-35.

JOGIANTO, H.M. 2014. Analisis dan Desain Sistem Informasi. Yogyakarta: Andi Offiset,

KADIR A., 2014. Pengenalan Sistem Informasi Edisi Revisi, Yogyakarta: Andi.

KOES, A \& RAHAJENG, 2014. Rancang Bangun Sistem Informasi Administrasi SPBU dan Upah Karyawan. Jurnal Ilmiah Go Infotech. 20(2),

MOLLY, B., TANAAMAH, A. R., \& SITOKDANA, 2017. Analisis Kinerja Sistem Informasi dan Teknologi Informasi untuk Menunjang Kinerja Karyawan Mengunakan Framework IT Balanced Scorecard (Studi kasus pada WI-FI Universitas Kristen Satya wacana). Jurnal Teknologi Informasi dan Ilmu Komputer (JTIK). 4(4). 318-332.

NATANAEL, B. \& MULYONO, H, 2017, Analisis dan Perancangan Sistem Informasi Penilaian Kinerja Karyawan Pada PT. BPR Universal Sentosa. Jurnal Manajemen Sistem Informasi. 2(1), 295-302

ROMNEY MARSHALL, Stainbart John Paul. 2015. Sistem Informasi Akuntansi., Jakarta: Salemba Empat.

ROSSA A.S, \& M. SHALAHUDDIN. 2013. Rekayasa Perangkat Lunak. Bandung: Modula.

SETIAWAN, A., \& YASDOMI, K. 2016. Analisa dan Perancangan Sistem Informasi Penggajian untuk Meningkatkan Efisiensi Karyawan (Studi kasus pada PT. Pabrik Obat Indonesia/POI). Journal Of Computer Science 2(1). 1 - 12

YUDIHARTANTI, Y., SYAHIB NATARSYAH, S., \& ARNIE, R. 2017. Rancangan sistem informasi Penilaian Kinerja akuntabilitas koperasi aspek Organisasi. Jurnal Simantec. 6(2), 91-96 
Halaman ini sengaja dikosongkan 